\title{
Determination of the Minerals of the Herbal Tea and Tea Green from Lippia multiflora
}

\author{
Ekissi Alice Christine ${ }^{*}$, Yao-Kouamé Albert², Kati-Coulibaly Séraphin ${ }^{3}$ \\ ${ }^{1}$ Biochemistry-Nutrition, Research Training Unit of Agroforestry, University Jean Lorougnon Guede of Daloa, Daloa, \\ Côte d'Ivoire \\ ${ }^{2}$ Faculty of Earth Sciences and Mineral Resources, University Felix Houphouet Boigny of Cocody-Abidjan, Abidjan, Côte d'Ivoire \\ ${ }^{3}$ Laboratory of Nutrition and Pharmacology, Faculty of Biosciences, University Felix HouphouetBoigny of Cocody-Abidjan, \\ Abidjan, Côte d'Ivoire \\ Email: *ekissialicec@gmail.com
}

How to cite this paper: Christine, E.A., Albert, Y.-K. and Séraphin, K.-C. (2017) Determination of the Minerals of the Herbal Tea and Tea Green from Lippia multiflora. American Journal of Plant Sciences, $\mathbf{8}$, 2608-2621.

https://doi.org/10.4236/ajps.2017.811176

Received: August 31, 2017

Accepted: October 9, 2017

Published: October 12, 2017

Copyright $\odot 2017$ by authors and Scientific Research Publishing Inc. This work is licensed under the Creative Commons Attribution International License (CC BY 4.0).

http://creativecommons.org/licenses/by/4.0/

\begin{abstract}
This study aims to determine the mineral composition of green teas and herbal tea in the savannah tea plant. Samples of buds, young leaves and broadleaf stems were collected from wild plants of Lippia multiflora in three localities, including two from the Center (Yamoussoukro, Toumodi) and one from the northeast (Bondoukou) of Côte d'Ivoire. The lipid and ash contents were carried out by the AOAC method. The total protein and sugar contents were determined by the Kjeldahl and Agbo methods, respectively. Nine minerals (potassium, calcium, magnesium, iron, sodium, manganese, zinc, copper and cadmium) were quantitated by Atomic Absorption Spectrophotometry (AAS) from green teas (buds and young leaves) and herbal tea of Lippia multiflora. The results showed that ash levels $(7.05 \%-13.94 \%)$ and protein $(6.22 \%-$ 9.97\%) were high, however the lipid contents $(1.01 \%-2.98 \%)$ and total sugars $(1.43 \%-4.51 \%)$ are low. Majority of the minerals are calcium (2320.91 to $36150.10 \mathrm{mg} / \mathrm{kg}$ ), potassium (2110.71 to $12174.67 \mathrm{mg} / \mathrm{kg}$ ) and magnesium $(3620.87-5870.46 \mathrm{mg} / \mathrm{kg})$. Iron $(52.55$ to $483.11 \mathrm{mg} / \mathrm{kg}$ ), sodium (35.66 to $469.16 \mathrm{mg} / \mathrm{kg}$ ) and manganese ( 15.25 to $76.86 \mathrm{mg} / \mathrm{kg}$ ) are represented in average proportions. There are small amounts of zinc $(9.61-47.50 \mathrm{mg} / \mathrm{kg})$, copper $(5.66-8.71 \mathrm{mg} / \mathrm{kg})$, and cadmium $(0.17-1.49 \mathrm{mg} / \mathrm{kg})$. Lippia multiflora herbal teas and green teas are low in fat, high in ash and are good sources of protein and minerals.
\end{abstract}

\section{Keywords}

Herbal Tea, Lippia multiflora, Buds, Young Leaves, Green Tea 


\section{Introduction}

Tea is one of the most popular drinks in the world. Thus, the chemical components contained in the tea leaves are of great interest, particularly with regard to health. Lippia multiflora, a savannah tea belonging to the Verbenaceae family, a herbaceous, perennial, very fragrant herb that spontaneously grows in savannah areas, hence its common name for savannah tea. This plant is found almost everywhere, in the Sudanese savannahs of West and Central Africa [1]. In Côte d'Ivoire, it is developing in the central and northern regions, where it is consumed as a hot drink [2] [3]. The leaves of the savannah tea plant are marketed throughout Côte d'Ivoire [3] and this has led to its consumption in rural and urban areas. This plant is appreciated for its pleasant aroma (citronella) [2]. In addition, the leaves of Lippia multiflora are used in traditional medicine, in the treatment of malaria, high blood pressure [4] boils, diarrhea [5] cough, stomach pain, fever, and oral affections [6]. In addition, numerous scientific publications have shown that Lippia multiflora possesses laxative properties, sedative, relaxing muscles, analgesics, tranquilizers, analgesics [7]. This plant has antihypertensive effects [8] antimicrobial activities [9].

The leaves of the savannah tea plant also exhibit insecticidal activities in relation to mosquitoes and weevils [10]. The composition of the essential oils of Lippia multiflora has been widely studied [11]. Phytochemical studies [2], botany [12] and medical studies [13] have been studied. From a biochemical point of view, it is a plant rich in minerals (potassium, calcium, magnesium), which also contains polyphenols [4]. Nowadays, the consumption of food, sources of polyphenols like the green tea of Camellia sinensis, having anti-carcinogenic, anti-cardiovascular activities [14]. The various medicinal, nutritional, flavoring and insecticidal properties mentioned above of Lippia multiflora make this plant a highly sought-after species, especially in savannah regions. But in these areas, this plant is threatened with extinction because of its abusive harvest, deforestation and bush fires [15]. It deserves to be valued, domesticated and exported. It deserves to be valued, domesticated and exported.

This natural plant could constitute a new agricultural product for the country alongside industrial and commercial crops (coffee, cocoa, rubber and cashew nuts). Although in Ghana, authors such as [16] have determined the mineral composition of the leaves of Lippia multiflora. Like other teas such as rosibos (red tea) from Aspalathus linearis from South Africa and Green Tea, black tea, Oolong Tea from Camellia sinensis. In Côte d'Ivoire, data on Lippia multiflora green teas and herbal teas are rare. The objective of this study is to determine the mineral composition of green teas and herbal teas of the savannah tea (Lippia multiflora), in order to evaluate the possible effects on the health of consumers.

\section{Materiel}

\section{Biological Materiel}

The leaves of the savannah tea (Lippia multiflora) were harvested in uncultivated 
areas from June to July 2010 in three localities: Yamoussoukro, Toumodi and Bondoukou in Côte d'Ivoire. Leaf picking takes place at different stages of development (buds and young leaves) and fresh leaf stems (Figure 1).

\section{Methods}

\subsection{Process for Transforming the Leaves of the Savannah Tea (Lippia multiflora) into Herbal Tea}

The leaves were transformed into herbal tea by the method described by [15]. The leafy stems are cut at the base of the shrub (Lippia multiflora) and dried in the sun for 3 to 5 days or 7 days depending on the season. After drying, the dried leaves are detached from the stems. The resulting dry leaves constitute the herbal tea. This herbal tea can be used in the form of whole or ground sheet or cut or chopped sheet (Figure 2).

\subsection{Process for Transforming the Leaves of Lippia multiflora into Green Tea}

The leaves were transformed into green tea by the orthodox method described by [17] with slight modification. Briefly, the leaves were sorted, dried in an oven (memmert) at $30^{\circ} \mathrm{C}$ for 8 to 10 hours, rolled by hand for 20 to 30 minutes and dried at $90^{\circ} \mathrm{C}-95^{\circ} \mathrm{C}$ of a memmert, for 30 minutes, this procedure was repeated after 15 minutes of rest until a dry product was obtained. The final dry product obtained is whole-leaf green tea. The green teas obtained were stored in plastic

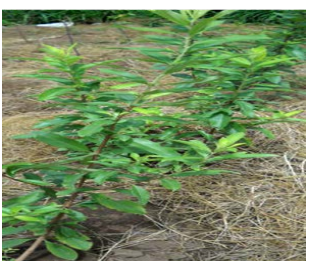

Lippia multiflora

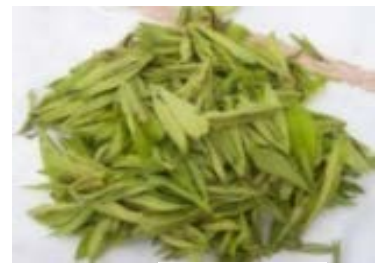

Buds

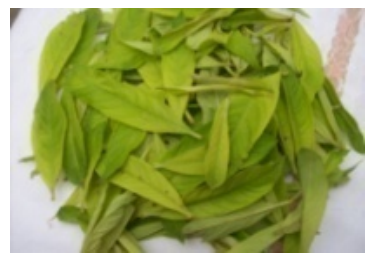

Young leaves

Figure 1. Photograph of buds, young leaves and Lippia multiflora.

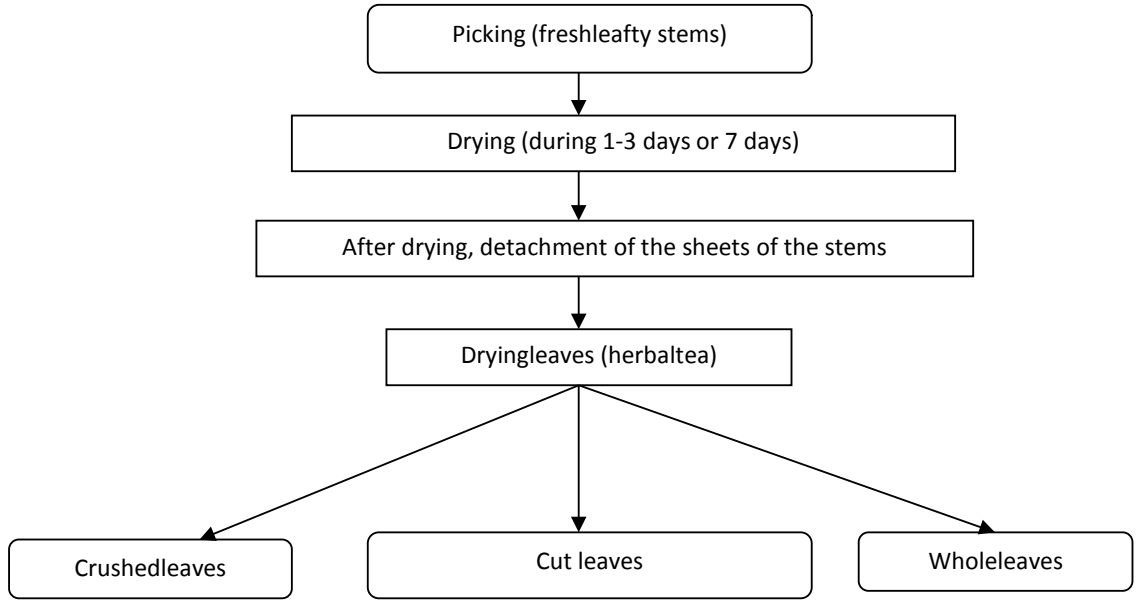

Figure 2. Traditional process diagram for obtaining Lippia multiflora herbal tea. 
bags that were placed in paper cans to avoid contact with air and light (Figure 3).

\subsection{Physico-Chemical Analysis of Green Teas and Herbal Teas from Lippia multiflora}

In Lippia multiflora green teas and herbal teas, the lipids and ash content were respectively evaluated according to [18] [19]. Protein levels were measured using the Kjedahl method [18] by mineralization of $1 \mathrm{~g}$ of each sample and titration of the total nitrogen after distillation. The total content of the sugars was measured according to the methods elaborated by [20] [21]. All determinations were expressed on a dry matter basis.

\subsection{Determination of Mineral Contents}

The mineral content was determined by the plant method of the International Institute of Tropical Agriculture of Nigeria [22]. This is a dry digestion method which proceeds as follows: $0.5 \mathrm{~g}$ of crushed sample is weighed in a porcelain crucible and then cooked (PROLABO) at $650^{\circ} \mathrm{C}$ for $5 \mathrm{~h}$. After cooling, $5 \mathrm{ml}$ of 1 mol. $\mathrm{L}^{-1}$ nitric acid are added to the ash obtained and then brought to total evaporation on a sand bath. The ash is returned to the muffle furnace at $400^{\circ} \mathrm{C}$ for 10 to $15 \mathrm{~min}$. To the residue are added $5 \mathrm{ml}$ of $0.1 \mathrm{~mol} \cdot \mathrm{L}^{-1}$ hydrochloric acid. The final residue was recovered with $10 \mathrm{ml}$ of $1 \mathrm{~mol} \cdot \mathrm{L}^{-1}$ hydrochloric acid and then poured into a $50 \mathrm{ml}$ flask by filtration. The crucible is rinsed three times with $10 \mathrm{ml}$ of hydrochloric acid. The flask is prepared up to $50 \mathrm{ml}$ with $0.1 \mathrm{~mol} / \mathrm{L}$ hydrochloric acid. The contents of the elements are obtained by analyzing the atomic adsorption spectrophotometer (AAS) with an air-acetylene flame.

\subsection{Statistical Analysis}

The data obtained from the analysis of the physicochemical and mineral constituents of the green teas and the tea sample with Lippia multiflora herbs were

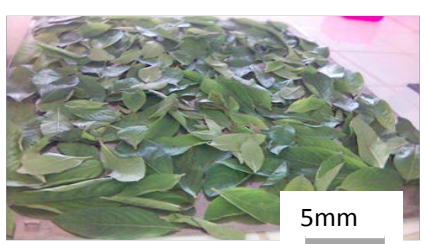

(a)

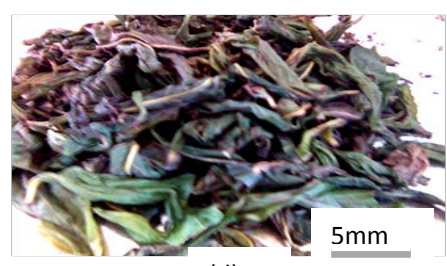

(d)

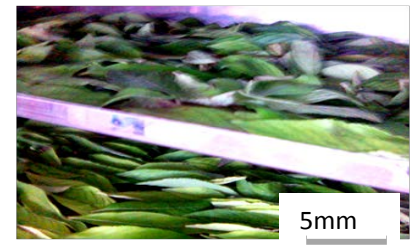

(b)

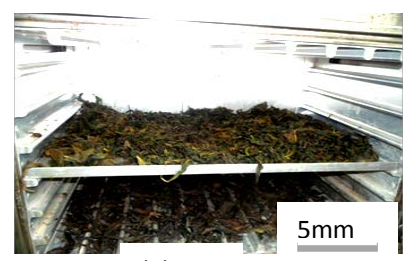

(e)

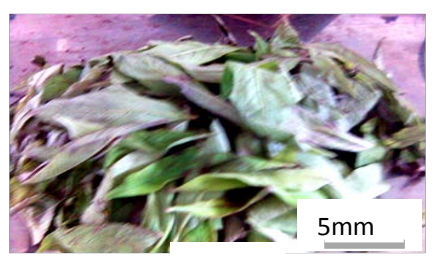

(c)

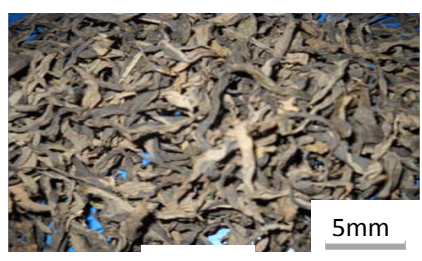

(f)

Figure 3. Steps of transformation of Lippia multiflora leaves into green tea. (a) fresh leaves, (b) withering leaves in the oven, (c) withered leaves, (d) rolled leaves; (e) desiccation of leaves in an oven, (f) whole leaf green tea. 
analyzed for variance (ANOVA) using the STATISTICA 7.1 software (six sig$\mathrm{ma}$ ). When the significant difference existed, the Tukey test was used to separate the means.

\section{Results}

\subsection{Biochemical Composition of Herbal Teas and Green Teas}

In all localities (Table 1$)$, herbal teas contain significantly $(\mathrm{p}<0.01)$ more ashes than green teas. However, the ashes contents of Bondoukou (13.94\% DM) and Toumodi (13.57\% DM) are stronger than those of Yamoussoukro (12.06\% DM). The ash rates in both localities are similar. Ash content of green teas of young leaves is stronger than green teas of buds, in all localities.

The lipid contents of herbal teas and teas are less than 3\%. These levels were significantly different $(\mathrm{p}<0.01)$ between herbal teas and green teas. There was no significant difference $(\mathrm{p}>0.01)$ between the lipid contents of green teas in different localities (Table 1).

The protein levels of herbal teas were 8.24 ; to; $8.86 \%$ DM in the localities of Yamoussoukro, Toumodi and Bondoukou. There is no significant difference ( $p>0.01$ ) between the protein content of herbal teas in these cities. The protein content of green teas in Yamoussoukro are significantly $(\mathrm{p}<0.01)$ higher than those of the localities of Toumodi and Bondoukou. On the other hand, there is no significant difference $(\mathrm{p}>0.01$ ) between the contents of the last two localities.

Table 1 indicates that the total sugars of the various products (herbal teas and green teas) are low at less than 5\% DM in all localities.

Table 1. Biochemical composition of herbal teas and green teas (bud and young leaves).

\begin{tabular}{|c|c|c|c|c|}
\hline \multirow{2}{*}{ compounds } & \multirow{2}{*}{ locality } & \multicolumn{3}{|c|}{ Different products of the savannah tea plant (Lippia multiflora) } \\
\hline & & Herbal tea & Green tea B & Green tea YL \\
\hline \multirow{3}{*}{ Ashes (\%DM) } & Yamoussoukro & $12.06 \pm 0.80 \mathrm{a}$ & $7.16 \pm 0.48 c$ & $8.07 \pm 0.27 b$ \\
\hline & Toumodi & $13.57 \pm 0.23 a$ & $8.63 \pm 0.19 c$ & $9.41 \pm 0.16 b$ \\
\hline & Bondoukou & $13.94 \pm 0.41 \mathrm{a}$ & $7 \pm 0.55 c$ & $8.07 \pm 0.71 b$ \\
\hline \multirow{3}{*}{ Lipids (\%DM) } & Yamoussoukro & $2.90 \pm 0.49 \mathrm{a}$ & $1.01 \pm 0.13 b$ & $1.11 \pm 0.17 \mathrm{~b}$ \\
\hline & Toumodi & $2.21 \pm 0.03 \mathrm{a}$ & $1.01 \pm 0.03 \mathrm{~b}$ & $1.24 \pm 0.06 \mathrm{~b}$ \\
\hline & Bondoukou & $2.98 \pm 0.58 \mathrm{a}$ & $1.03 \pm 0.18 b$ & $1.29 \pm 0.32 b$ \\
\hline \multirow{3}{*}{ Protens $(\% \mathrm{DM})$} & Yamoussoukro & $8.24 \pm 1.12 b$ & $9.97 \pm 0.51 \mathrm{a}$ & $8.10 \pm 1.19 b$ \\
\hline & Toumodi & $8.24 \pm 0.04 \mathrm{a}$ & $7.74 \pm 0.07 \mathrm{~b}$ & $6.26 \pm 0.02 c$ \\
\hline & Bondoukou & $8.86 \pm 0.56 a$ & $7.59 \pm 0.37 b$ & $6.22 \pm 0.87 c$ \\
\hline \multirow{3}{*}{$\begin{array}{l}\text { total Sugars } \\
\text { (\% DM) }\end{array}$} & Yamoussoukro & $2.77 \pm 0.11 \mathrm{a}$ & $2.12 \pm 0.57 \mathrm{a}$ & $1.73 \pm 0.42 b$ \\
\hline & Toumodi & $4.51 \pm 0.13 \mathrm{a}$ & $2.78 \pm 0.05 b$ & $1.93 \pm 0.06 \mathrm{c}$ \\
\hline & Bondoukou & $3.74 \pm 0.77 \mathrm{a}$ & $1.43 \pm 0.40 \mathrm{~b}$ & $1.75 \pm 0.42 \mathrm{~b}$ \\
\hline
\end{tabular}

Means followed by different letters in the same line are significantly different $(\mathrm{p}<0.01)$. Green tea B = green tea of buds; Green tea YL $=$ green tea of young leaves. 


\subsection{Mineral Composition of Herbal Tea and Green Teas from Lippia multiflora}

\section{Magnesium (Mg)}

Table 2 shows the magnesium contents of savannah tea plant products. In all localities, there is a significant difference $(\mathrm{p}<0.01)$ between the different products (herbal teas, green tea of buds and green tea of young leaves). In the localities of Toumodi and Bondoukou, herbal teas show higher levels of magnesium,

Table 2. Minerals compositions of herbal teas and green teas (bud and young leaves).

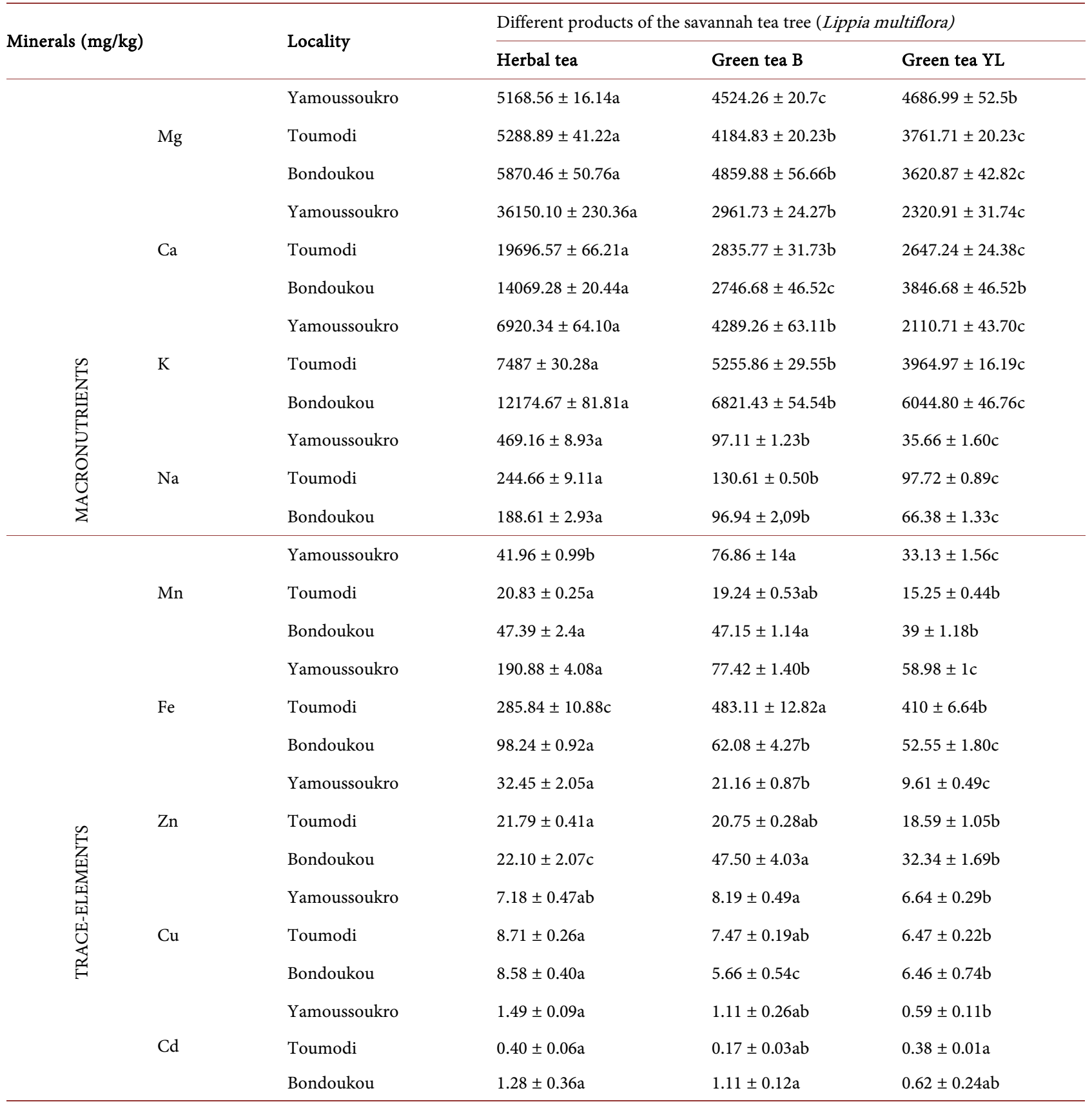

Means followed by different letters in the same line are significantly different $(\mathrm{p}<0.01)$; Green tea $\mathrm{B}=$ green tea of buds; Green tea $\mathrm{YL}=$ green tea of young leaves. 
respectively, of 5288.89 and $5870.46 \mathrm{mg} / \mathrm{kg}$, followed by those of green buds teas; green tea young leaves have the lowest grades. However, in Yamoussoukro, magnesium levels are high in herbal teas, followed by green teas young leaves, green teas buds show low levels. At the level of the different products, there is a significant difference $(\mathrm{p}<0.01)$ between the different localities. Indeed, for herbal teas, the city of Bondoukou contains the high rates, followed by Toumodi, and Yamoussoukro. However, for green teas buds, the city of Bondoukou records high grades, followed by the locality of Yamoussoukro, and Toumodi displays the low rates. Concerning green teas young leaves, the city of Yamoussoukro has strong values, followed by Toumodi, and Bondoukou has the lowest rates.

\section{Calcium (Ca)}

Within each locality, calcium levels are significantly different $(\mathrm{p}<0.01)$ between different types of products. In Yamoussoukro and Toumodi, calcium levels were higher in herbal teas (36150.10 and $19696.57 \mathrm{mg} / \mathrm{kg}$ ), respectively, in Yamoussoukro and Toumodi, followed by the levels of green teas (2961.73 and $2835.77 \mathrm{mg} / \mathrm{kg}$ ), successively, in Yamoussoukro, Toumodi and Bondoukou, and finally, the green teas of young leaves contain the lowest levels, respectively, 2320.91; and $2647.24 \mathrm{mg} / \mathrm{kg}$, in Yamoussoukro and Toumodi. However, in Bondoukou, high levels are recorded by herbal teas, followed by green teas young leaves, and green teas buds contain low grades. For each type of product, there is a significant difference $(\mathrm{p}<0.01)$ between the different localities. Indeed, for herbal teas and green teas buds, the city of Yamoussoukro has high calcium contents, followed by those of Toumodi and Bondoukou. However, for the green teas young leaves, the locality of Bondoukou is the one that records the high calcium levels, followed by Toumodi, and Yamoussoukro.

\section{Potassium (K)}

The potassium levels of the different Lippia multiflora products in all localities showed a significant difference $(\mathrm{p}<0.01)$ between the different types of products (herbal teas, green tea of buds and green tea of young leaves).In all towns, the potassium levels in herbal teas, respectively, $6920.34,7487$ and $12174.67 \mathrm{mg} / \mathrm{kg}$ in Yamoussoukro, Toumodi and Bondoukou are stronger, then follow the levels of green teas of buds 4289, 265, 5255.86 and $6821.43 \mathrm{mg} / \mathrm{kg}$, respectively, in Yamoussoukro, Toumodi and Bondoukou, and those green teas of young leaves (2110.71, 3964.97 and $6044.80 \mathrm{mg} /$ in Yamoussoukro, Toumodi and Bondoukou. At the level of each type of product, there is a significant difference $(\mathrm{p}<0.01)$ between the different localities. Indeed, for all products, the city of Bondoukou records the highest potassium levels, followed by those of Toumodi, and Yamoussoukro.

\section{Sodium $(\mathrm{Na})$}

In all localities, there is a significant difference $(\mathrm{p}<0.01)$ between the different types of products. In all cities, herbal teas contain high levels of sodium, respectively, 469.16; 244.66 and $188.61 \mathrm{mg} / \mathrm{kg}$, in Yamoussoukro, Toumodi and Bon- 
doukou, then follow the green teas of buds $97.11 ; 130.61$ and $96.94 \mathrm{mg} / \mathrm{kg}$, in Yamoussoukro, Toumodi and Bondoukou, and the green teas of young leaves were the lowest, respectively, at 35.66; 97.72 and $66.38 \mathrm{mg} / \mathrm{kg}$ in Yamoussoukro, Toumodi and Bondoukou. At the level of each type of product, the sodium levels are significantly different between all the cities. Indeed, for herbal teas, the city of Yamoussoukro records the highest levels of sodium. However, concerning the green teas of buds, the locality of Toumodi contains the high grades and the city of Bondoukou gives the low grades. In the case of green teas of young leaves, the locality of Toumodi presents the high grades and the city of Yamoussoukro records the low grades.

\section{Manganese (Mn)}

At the level of manganese levels, there is a significant difference $(p<0.01)$ for each type of product between the different localities. For herbal teas and green teasof young leaves, the city of Bondoukou contains high grades, followed by Yamoussoukro, and the town of Toumodi has low rates. However, at the level of green teas buds, Yamoussoukro has the highest manganese content, followed by Bondoukou, and the low levels come from Toumodi.

\section{Iron (Fe)}

The iron content of Lippia multiflora products is shown in Table 2. Within each locality, there is a significant difference $(\mathrm{p}<0.01)$ between the different types of products. Indeed, in Yamoussoukro and Bondoukou, the iron contents are stronger in herbal teas, followed by green teas of buds, and green teas of young leaves contain the low grades. However, in Toumodi, iron levels are strong in green teas of buds, followed by those of green teas young leaves, and herbal teas record low grades. For each type of product, there is a significant difference $(\mathrm{p}<0.01)$ between the different localities. For each type of product, the city of Toumodi has the highest iron content, followed by Yamoussoukro, and low rates are recorded in Bondoukou

\section{Zinc (Zn)}

Lippia multiflora has a significant difference $(\mathrm{p}<0.01)$ between the zinc levels of the different localities for each type of product (herbal teas, green tea of buds and green teas of young leaves). Within all localities, there are significant differences $(\mathrm{p}<0.01)$ between the various products of the savannah tea plant.

\section{Copper $(\mathrm{Cu})$}

At the level of each city, the copper contents of the different savannah tea products are significantly different $(\mathrm{p}<0.01)$. Indeed, herbal teas contain higher grades than green teas of young leaves. However, there is no significant difference ( $p>0.01$ ) between green teas of young leaves of all localities

\section{Cadmium (Cd)}

The cadmium content of the various products of the savannah tea plant is low, not exceeding $2 \mathrm{mg} / \mathrm{kg}$. These rates are not significantly different ( $\mathrm{p}>0.01)$ between all localities. 


\section{Discussion}

Green teas and herbal teas have protein contents $(6 \%$ - 9\%) close to [23]. However, their contents are low in lipids (less than 3\%) and in low total sugars. This could mean that Lippia multiflora products are good protein sources. Low lipid levels corroborate the findings of studies by [24], which stipulate that the leaves generally contain little lipids. According to the results, these low levels of lipids and total sugars indicate that the teas and herbal tea of Lippia multiflora could be consumed without risk of hyperglycemia by diabetics and obese individuals reported by [25]. The high ash content of the savannah tea products leads us to say that Lippia multiflora teas and herbal teas are good sources of minerals, because ash is residues of mineral compounds which persist after the incineration of a sample containing organic substances of animal and vegetable origin [26].

The magnesium composition of the green teas of the savannah tea tree shows higher levels (3620.87 to $4859.88 \mathrm{mg} / \mathrm{kg}$ ) than those of [27] in green tea from Camellia sinensis. Lippia multiflora herbal teas are also rich in magnesium and the content is higher than that of the South African honey bush tea analyzed by [28]. Calcium is one of the mineral elements essential to the growth of a plant. The calcium levels of green teas and Lippia multiflora herbal teas, of the order of 2320.91 to $36150.10 \mathrm{mg} / \mathrm{kg}$ are similar to those determined by [27] in Camellia sinensis green tea. The recommended daily intake for calcium is 340 to $1200 \mathrm{mg}$ per day for children and $900 \mathrm{mg} /$ day for adults [29]. High levels of calcium in Lippia multiflora herbal teas and green teas could be a good source of nutrients for elderly people prone to osteoporosis [30], and the consumption of these leaves may be recommended in people suffering from osteoporosis hypocalcemia. Because calcium is an essential element in many vital functions of the body (coagulation of blood, maintenance of blood pressure, construction and maintenance of bones and teeth, cofactor in the enzymatic process) [31] [32]. Potassium is one of the various mineral elements that the plant needs for its growth. Potassium also intervenes in the regulation of growth, which is why the rate is higher in the buds that constitute the areas of growth of the plant. The green teas of Lippia multiflora have potassium levels of 2110.71 to $6821.43 \mathrm{mg} / \mathrm{kg}$. These levels are low compared to those obtained by the authors [27] [33] in Camellia senensis teas. The low sodium content of teas and herbal teas could be used in the treatment of hypertension and renal disease according to [34]. The potassium levels of herbal teas and green teas are higher than those of sodium. This would mean that the consumption of herbal teas and green tea from the savanna tea tree could prevent high blood pressure [35] [36] [37]. The beneficial effect of a sodium restriction on the control of arterial hypertension is increased by a concomitant increase in potassium intake [38]. The manganese levels (15.25 to $76.86 \mathrm{mg} / \mathrm{kg}$ ) in Lippia multiflora green teas are similar to those obtained by [39] for Camellia sinensis green tea. These values are lower than those obtained by the authors [27] [33] [39] in the green teas of Camellia sinensis. The manganese contents (20.83 to $47.39 \mathrm{mg} / \mathrm{kg}$ ) of herbal teas are lower than the value found in 
[40] in herbal teas (South American). Iron is an essential trace element for human growth. The levels of green teas and herbal teas are of the order of 52.55 to $483.11 \mathrm{mg} / \mathrm{kg}$. These levels are similar to those obtained by [27], who reported an average value of $241 \mathrm{mg} / \mathrm{kg}$ in Camellia sinensis green teas. These levels are higher than the recommended daily intake of 3.9 to $21.8 \mathrm{mg} /$ day for children, 9.1 $\mathrm{mg} /$ day for males and $19.6 \mathrm{mg} /$ day for females [41]. Lippia multiflora green teas are therefore good sources of iron. Therefore, the supplementation of Lippia multiflora products in a diet could help combat the iron deficiency anemia that affects one billion people worldwide [42]. Zinc is an essential trace element for the growth, development and maintenance of immune function, which strengthens the prevention and cure of infectious diseases [43]. Meat products are the best source of zinc [43] and zinc deficiency is usually observed in populations consuming low-protein diets. The levels in green teas $(9.61$ to $47.50 \mathrm{mg} / \mathrm{kg}$ ) and herbal teas $(21.79$ to $32.45 \mathrm{mg} / \mathrm{kg})$ are close to those obtained by [27] in the green teas of Camellia sinensis and [44] in herbal tea mate.

Copper is a trace element that plays an essential role in various metabolisms, including cartilage quality, bone mineralization, neurotransmitter peptide synthesis and regulation, iron immunity and metabolism, oxidative metabolism of glucose and is therefore essential to the functioning of the myocardium [32]. The concentration of copper $(5.66-8.19 \mathrm{mg} / \mathrm{kg})$ in green teas is lower than that obtained by [27] [45] in Camellia sinensis teas. Copper levels ( 7.18 to $8.71 \mathrm{mg} / \mathrm{kg}$ ) in herbal teas are similar to those reported by [44] in herbal tea mate. Cadmium levels in green tea and herbal teas are low and do not exceed $3 \mathrm{mg} / \mathrm{kg}$. These results are in agreement with those of [46], where in normal plants the cadmium content of leaves is between $0.1-3 \mu \mathrm{g} / \mathrm{g}$ DM. However, these values are higher than those of [45] who obtained rates ranging from 0.05 to $0.38 \mathrm{mg} \mathrm{kg}$ on $\mathrm{Ca}$ mellia sinensis black teas from southern India. This low cadmium content of Lippia multiflora is explained by the fact that most of the accumulated cadmium remains in the roots, only small quantities are transported to the aerial parts [47] [48]. These authors showed that in wheat, $78 \%$ of cadmium is retained in the roots. The green teas and herbal teas of Lippia multiflora are rich in minerals and these are distributed in a varied way. Variations in the minerals found in the different localities studied and the different types of products could be related to the geographic origin of the leaves and the age of the leaves, as shown by [45] [49] [50]. In fact, the cities of the Center (Yamoussoukro and Toumodi) have ferralsol soils [51], the climate is Baouléen [52], characterized by four seasons (two rainy seasons and two dry seasons). While the northeastern city of Bondoukou has tropical ferruginous soil [53] [54], the climate is Sudanian, characterized by two seasons (one long dry season and one short rainy season) [53].

\section{Conclusions}

The study reveals that the green teas and teas of the savannah tea plant are rich in ash, protein, but low in lipids and in total sugars. The products of Lippia 
multiflora are good sources of minerals whose main elements are potassium, calcium and magnesium. Iron, sodium and manganese are present in average proportions. The others, namely zinc, copper and cadmium, exist in small quantities. Given the mineral wealth of herbal teas and green teas of Lippia multiflora, it could be introduced into food formulations.

These results could also lead the food industry to focus on Lippia multiflora (an underutilized wild plant) by transforming its leaves into tea and herbal tea. This could constitute a new agricultural product for the country, serving as a source of income for the population, thus fighting against poverty.

\section{Acknowledgements}

We thank: the Program for Strategic Support to Scientific Research in Côte d'Ivoire (PASRES) for their funding, the Swiss Center for Scientific Research in Côte d'Ivoire (CSRS), the National Polytechnic Institute Félix Houphouet Boigny of Yamoussoukro (Côte d'Ivoire) and the Ivorian Society of Tropical Technology (I2T) for their valuable support.

\section{References}

[1] Jim, S., Wudeneh, L., Mariana, S. and Dan, A. (2001) Agribusiness in Sustainable Natural African Plant Product Lippia Tea. PhD, Jessimonaesop Rutgers Edu. Center for New Use Agriculture and Natural Plant Products, 2 p.

[2] Kanko, C., Koukoua, G., N'guessan, Y.T., Fournier, J., Pradere, J.P. and Toupet, L. (2004a) Contribution àl'étude phytochimique de Lippia multiflora (Verbenaceae). CRC Press, 7, 1029-1032.

[3] N'guessan, K.A., and Yao-Kouamé, A. (2010) Filière de commercialisation et usages des feuilles de Lippiamultiflora en Côte d'Ivoire. Journal of Applied Biosciences, 29, 1743-1752.

[4] Pascua,1 M.E., Slowing, K., Carretero, E., Sánchez, D.M. and Villar, A. (2001) Lippia: Traditional Uses, Chemistry and Pharmacology: A Review. Journal of Ethnopharmacology, 76, 201-214. https://doi.org/10.1016/S0378-8741(01)00234-3

[5] Ouedraogo, O.G. (1986) Plantes médicinales et pratiques médicales traditionnelles du Burkina Faso: cas du plateau central. Thèse de l' Université de Ouagadougou, $261 \mathrm{p}$.

[6] Kerharo M. and Adam, A. (1974). La pharmacopée sénégalaise traditionnelle. Edition Vigot et Frères, Paris, $778 \mathrm{p}$.

[7] Abena, A.A., Diatewa, M., Gakossi, G., Gbeassor, M., Hondi-Assah, T.H. and Ouamba, J.M. (2003) Analgesic, Antipyretic and Anti-Inflammatory Effects of Essential oil of Lippia multiflora. Fito, 74, 231-236. https://doi.org/10.1016/S0367-326X(03)00029-7

[8] Koffi, Y.J.P. (1985) Recherche Phytochimique et pharmacologique sur trois Verbnaceae à utiliser comme antihypertenseur en médecine traditionnelle: Lippia multiflora, lantana camaraL. et GmeliaarboreaMond. Thèse de Doctorat de 3ème cycle, Université d Toulouse III, France, 281 p.

[9] Oussou K.R., Yolou, S., Boti J.B., Guessennd, K.N, Kanko, C., Ahibo, C. and Casanova, J. (2008) Etude chimique et activité antidiarrheique des huiles essentielles de deux plantes aromatiques de la pharmacopée ivoirienne. European Journal of Scientific Research, 24, 94-103. 
[10] Koumaglo, K.H., Akpagana, K., Glitho, A.I., Garneau, F.X., Gagnon, H., Jean, F.I., Moudachirou, M. and Addae-Mensah, I. (1996) Geranial and General Major Constituents of Lippia multiflora Moldenke Leaf Oil. Journal of Essential Oil Research, 8, 237-240. https://doi.org/10.1080/10412905.1996.9700608

[11] Tia, V.E., Adima, A.A., Niamke, L.S., Gnago, A.J., Thibaud, M., Lozano, P. and Menut, C. (2011) Chemical Composition and Insecticidal Activity of Essential Oils of Two Aromatic Plants from Ivory Coast against Bemisiatabaci G. (Hemiptera: Aleyrodidae). Natural Product Communications, 6, 1-6.

[12] Alui, K.A., Yao-Kouame, A., Ballo, K.C., Kouadio, K.P., N'guessan, K.A. and Nangah, K.Y. (2011) Comportement de deux morphotypes de Lippia multiflora (Verbenaceae) sur ferralsols de la région de Yamoussoukro, Côte d'Ivoire. Journal of Applied Biosciences, 38, 2592-2601.

[13] Benoit-Vical, F., Valentin, A., Pelissier, Y., Marion, C., Milhan, M., Maillie, M., Bastide, J.M., Diafouka, F., Kone, B.D., Malan, A., Kone, M., Loukou, Y., Monet, D., Ake, A. and Yapo, A. (1996) Confirmation in vitro de l'activité antimalarique de certaines plantes d'origine Africaine utilisées en médecine traditionnelle. Médecine d'Afrique Noire, 43, 393-400.

[14] Hodgson, J.M. (2008) Tea Flavonoids and Cardiovascular Disease. Asia Pacific Journal of Clinical Nutrition, 17, 288-290.

[15] Ekissi A.C., Yao-Kouamé, A., Konan, A.G., Alui, K.A., Agbo, N.G. and Kati-Coulibaly, S. (2013) Manufacturing Process and Various Uses of Savannah Herbal Tea (Lippia multiflora) in Côte d'Ivoire. Asian Journal of Agriculture and Rural Development, 3, 597-608.

[16] Annan, K., Sante, I.K., Asare, C., Asare-Nkansah, S. and Tunkumgnen, B.M. (2011) Profile of Heavy Metals in Some Medicinal Plants from Ghana Commonly Used as Components of Herbal Formulations. Pharmacognosy Research, 2, 41-44. https://doi.org/10.4103/0974-8490.60579

[17] Coves, S. (2000) Le thé: de la feuille à la tasse. Cahiers De Nutrition, 35, 9-11.

[18] BIPEA (1976) Recueil des méthodes d'analyses des communautés européennes. 140 p.

[19] AOAC (1975) Official Method of Analysis. 11th Edition, AOAC, Washington DC, 51-52.

[20] Agbo, N.G., Uebersax, M. and Hosfield, G. (1985) An Efficient Extraction Technique of Sugars from Dry Edible Beans (Phaseolus vulgaris and Estimation an HPLC. Université Nationale de Côte d'Ivoire, Annales série C (Sciences), Tome XXI, $10 \mathrm{p}$.

[21] Dubois, M., Gilles, K.A., Hamilton, J.K., Robben, F.A. and Smith, F. (1956) Colorimetric Method for Determination of Sugar and Related Substances. Analytical Chemistry, 28, 350-356. https://doi.org/10.1021/ac60111a017

[22] IITA (1981) Analyse des prélèvements pédologiques et végétaux. Manuel No. 1, Oyo-Road, Nigéria, 66 p.

[23] Edeas, M. (2011) Les secrets de santé du thé. Ed. Alpen, Monaco, 95 p.

[24] Vodouhe, S., Dovoedo, A., Anihouvi, V.B., Tossou, R.C. and Soumanou, M.M. (2012) Influence du mode de cuisson sur la valeur nutritionnelle de Solanum macrocarpum, Amaranthus hybridus et Ocimum gratissimum, trois légumesfeuilles traditionnels acclimatés au Bénin. International Journal of Biological and Chemical Sciences, 6, 1926-1937.

[25] Lintas, C. (1992) Nutritional Aspects of Fruits and Vegetables Consumption. Options Mediterraeennes, 19, 79-87. 
[26] Audigié, C.L. and Zanzain, F. (1977) Manipulation d'analyses biochimiques. Doin edition, Paris, $274 \mathrm{p}$.

[27] McKenzie, J.S., Jurado, J.M. and De Pablos, F. (2010) Characterisation of Tea Leaves According to Their Total Mineral Content by Means of Probabilistic Neural Networks. Food Chemistry, 123, 859-864. https://doi.org/10.1016/j.foodchem.2010.05.007

[28] Olivier, J., Symington, E.A., Jonker, C.Z., Rampedi, I.T. and Van Eeden, T.S. (2012) Comparison of the Mineral Composition of Leaves and Infusions of Traditional and Herbal Teas. South African Journal of Science, 108, 1-7. https://doi.org/10.4102/sajs.v108i1/2.623

[29] Anonyme (2009) Conseil supérieur de la santé. Recommandation nutritionnelle pour la belgique. $92 \mathrm{p}$.

[30] Garriguet, D. (2011) Santé des os: Ostéoporose, calcium et vitamine D. Rapports sur la santé, 22, 1-9.

[31] Akubugwo, I.E., Obas,i N.A., Chinyere, G.C. and Ugbogu, A.E. (2007) Nutritional and Chemical Value of Amaranthus hybridus L. Leaves from Nigeria. African Journal of Biotechnology, 6, 2833-2839. https://doi.org/10.5897/AJB2007.000-2452

[32] Alais, C., Linden, G. And Miclo, L. (2008) Biochimie alimentaire. 6e éDition, Dunod, Paris, $260 \mathrm{p}$.

[33] Fernandez-Caceres, P.L., Martin, M.J., Pablos, F. and Gonzalez, A.G. (2001) Differentiation of Tea (Camelia sinensis) Varieties and Their Geographical Origin According to Their Metal Content. Journal of Agricultural and Food Chemistry, 49, 4775-4779. https://doi.org/10.1021/jf0106143

[34] Emebu, P.K. and Anyika, J.U. (2011) Proximate and Mineral Composition of Kale (Brassica oleracea) Grown in Delta State, Nigeria. Pakistan Journal of Nutrition, 10, 190-194. https://doi.org/10.3923/pjn.2011.190.194

[35] FNB (2002) Food and Nutrition Board. Dietary Reference Intake for Energy, Carbohydrate, Fiber, Fat, Fatty Acids, Cholesterol, Protein and Amino Acid (Micro-Nutrients). Inst. Med. Natl. Acad. Sci., 12 p.

[36] Adrogue, H.J. and Madias, N.E. (2007) Sodium and Potassium in the Pathogenesis of Hypertension. The New England Journal of Medicine, 356, 1966-1978. https://doi.org/10.1056/NEJMra064486

[37] Adepoju, O.T. and Oyewole, E.O. (2008) Nutritional Importance and Micronutrient Potentials of Two Non-Convectional Indigenous Green Leafy Vegetables from Nigeria. Agricultural Journal, 3, 362-365.

[38] Geleijnse, J.M., Kok, F.J. and Grobbee, D.E. (2003) Blood Pressure Response to Changes in Sodium and Potassium Intake: A Metaregression Analysis of Randomised Trials. Journal of Human Hypertension, 17, 471-480.

https://doi.org/10.1038/sj.jhh.1001575

[39] Reto, M., Figueira, M.E., Filipe, H.M.A. and Almeida, C.M.M. (2007) Chemical Composition of Green Tea (Camellia sinensis) Infusions Commercialized in Portugal. Plant Foods for Human Nutrition, 62, 139-144. https://doi.org/10.1007/s11130-007-0054-8

[40] Heck, C.I. and De Mejia, E.G. (2007) Yerba Mate Tea (Ilex paraguariensis): A Comprehensive Review on Chemistry, Health Implications, and Technological Considerations. Journal of Food Science, 72, 138-151. https://doi.org/10.1111/j.1750-3841.2007.00535.x

[41] Anonym (2004) Role of Iron in Human Metabolic. Processes, 246-278. 
[42] Trowbridge, F. and Martorell, M. (2002) Forging Effective Strategies to Combat Iron Deficiency Summary and Recommendations. Journal of Nutrition, 85, 875-880.

[43] Walker, C.F., Kordas, K., Stoltzfus, R.J. and Black, R.E. (2005) Interactive Effects of Iron and Zinc on Biochemical and Functional Outcomes in Supplementation Trials. The American Journal of Clinical Nutrition, 82, 5-12.

[44] Malik, J., Szakova, J., Drabek, O., Balik, J. and Kokoska, L. (2008) Determination of Certain Micro and Macroelements in Plant Stimulants and Their Infusions. Food Chemistry, 111, 520-525. https://doi.org/10.1016/j.foodchem.2008.04.009

[45] Seenivasan, S., Manikandan, N., Muraleedharan, N.N. and Selvasundaram, R. (2008) Heavy Metal Content of Black Teas from South India. Food Control, 19, 746-749. https://doi.org/10.1016/j.foodcont.2007.07.012

[46] Reeves, R.D. and Baker, A.J.M. (2000) Metal-Accumulating Plants. In: Raskin, I. and Ensley, B.D., Eds., Phytoremediation of Toxic Metals-Using Plants to Clean Up the Environment, John Wiley and Sons, New York, 193-229.

[47] Zhang, G., Fukami, M. and Sekimoto, H. (2000) Genotypic Differences in Effects of Cadmium on Growth and Nutrient Compositions in Wheat. Journal of Plant Nutrition, 23, 1337-1350. https://doi.org/10.1080/01904160009382104

[48] Aoun, M. (2009) Action du cadmium sur les plants de moutarde indienne [Brassicajuncea (L.) Czern] néoformés à partir de couches cellulaires minces et issus desemis. Analyses physiologiques et rôle des polyamines. Thèse de doctorat à l'Université de Bretagne Occidentale, Brest, 135 p.

[49] Costa, L.M., Gouveia, S.T. and Nobrega, J.A. (2002) Comparison of Heating Extraction Procedures for $\mathrm{Al}, \mathrm{Ca}, \mathrm{Mg}$ and $\mathrm{Mn}$ in Tea Samples. Annals of Science, 18, 313-318.

[50] Sahrawat, K.L. and Sika, M. (2002) Direct and Residual Phosphorus Effects on Soil Test Values and Their Relationships with Grain Yield and Phosphorus Uptake of Upland Rice on Ultisol. Communications in Soil Science and Plant Analysis, 33, 321-332. https://doi.org/10.1081/CSS-120002748

[51] Legros, J.P. (2007) Les grands sols du monde. Sciences et technologie de l'Environnement, Presses Polytechniques et Universitaires Romandes, Sciences de la terre, $574 \mathrm{p}$.

[52] Avenard, J.M., Eldin, M., Girard, G., Sircoulon, J., Touchebeuf, P., Gillaumet, J.L., Adjanohoun, E. and Perraud, A. (1971) Le milieu naturel de la Côte d'Ivoire. IRD Editions, Montpellier.

[53] Dabin, B., Leneuf, N. and Riou, G. (1960) Carte pédologique de la Côte d'Ivoire au 1 - 2.000.000. Imprimerie nationale, Abidjan, $31 \mathrm{p}$.

[54] Morel, R. (2004) Le climat et l'implantation des hommes: le cas de la Côte d'Ivoire. Journal de l'Association Internationale de Climatologie, 1, 117-132.

https://doi.org/10.4267/climatologie.1049 